\title{
Variations in Soil Microbial Communities and Residues Along an Altitude Gradient on the Northern Slope of Changbai Mountain, China
}

\author{
Bin Zhang ${ }^{1,2}$, Chao Liang ${ }^{3}$, Hongbo He ${ }^{1 *}$, Xudong Zhang ${ }^{1,4_{*}}$ \\ 1 State Key Laboratory of Forest and Soil Ecology, Institute of Applied Ecology, Chinese Academy of Sciences, Shenyang, P. R. China, 2 Graduate University of Chinese \\ Academy of Sciences, Beijing, P. R. China, 3 Department of Soil Science, University of Wisconsin-Madison, Madison, Wisconsin, United States of America, 4 National Field \\ Observation and Research Station of Shenyang Agroecosystems, Shenyang, P. R. China
}

\begin{abstract}
Altitudinally-defined climate conditions provide specific vegetation types and soil environments that could influence soil microbial communities, which in turn may affect microbial residues. However, the knowledge is limited in terms of the degree to which microbial communities and residues present and differ along altitude. In this study, we examined the soil microbial communities and residues along the northern slope of Changbai Mountain, China using phospholipid fatty acid (PLFA) and amino sugar analysis, respectively. Soil samples were taken from five different vegetation belts defined by climates. Principal component analysis (PCA) revealed substantial differences in soil microbial community composition among study sites, appeared to be driven primarily by soil $\mathrm{pH}$ and $\mathrm{C} / \mathrm{N}$ ratio on the first principal component (PC1) which accounted for $50.7 \%$ of the total sample variance. The alpine tundra was separated from forest sites on the second principal component (PC2) by a signifiscantly higher amount of fungal PLFA $(18: 2 \omega 6,9)$. Soil $\mathrm{pH}$ and $\mathrm{C} / \mathrm{N}$ ratio were also correlated with the ratios of Gram-positive to Gram-negative bacteria $\left(\mathrm{Gm}^{+} / \mathrm{Gm}^{-}\right)$, glucosamine to galactosamine (GluN/GalN), and glucosamine to muramic acid (GluN/MurA). Both total PLFAs and amino sugars were positively correlated with soil organic carbon, inorganic nitrogen, available phosphorus and potassium. We concluded that soil $\mathrm{pH}$ and $\mathrm{C} / \mathrm{N}$ ratio were the most important drivers for microbial community structure and amino sugar pattern, while substrate availability was of great importance in determining the concentrations of microbial communities and residues. These findings could be used to facilitate interpretation of soil microbial community and amino sugar data derived from measurements in latitude or managed forests.
\end{abstract}

Citation: Zhang B, Liang C, He H, Zhang X (2013) Variations in Soil Microbial Communities and Residues Along an Altitude Gradient on the Northern Slope of Changbai Mountain, China. PLoS ONE 8(6): e66184. doi:10.1371/journal.pone.0066184

Editor: Hauke Smidt, Wageningen University, The Netherlands

Received January 30, 2013; Accepted May 2, 2013; Published June 11, 2013

Copyright: (C) 2013 Zhang et al. This is an open-access article distributed under the terms of the Creative Commons Attribution License, which permits unrestricted use, distribution, and reproduction in any medium, provided the original author and source are credited.

Funding: This work was supported by the National Key Basic Research Foundation of China (2011CB403202), the Natural Science Foundation of China (41130524) and the International Partnership Program of Chinese Academy of Sciences (KZCX2-YW-T06). The funders had no role in study design, data collection and analysis, decision to publish, or preparation of the manuscript.

Competing Interests: The authors have declared that no competing interests exist.

*E-mail: hehongbo@iae.ac.cn (HH); xdzhang@iae.ac.cn (XZ)

\section{Introduction}

Soil microorganisms are of great importance to carbon $(\mathrm{C})$ and nitrogen $(\mathrm{N})$ cycling and storage [1], [2], ecosystem functioning [3], and global climate change [4]. Soil microbial communities have consequently received great interests for decades. It is well documented that a number of biotic and abiotic factors, such as vegetation type [5-8], temperature [9], water content [10], $\mathrm{pH}$ [11], [12], soil type [13], and soil depth [14], influence soil microbial communities, which in turn may affect the turnover and accumulation of soil microbial residues. Our understanding of soil microorganisms and their interactions with environmental factors is improving; however, the influences of climatic regimes on soil microbial communities and residues are still insufficiently investigated, with some existing studies on latitude [15-17] but little attention to altitude. The altitudinally-defined vegetation belts on mountain slopes are counterparts to the latitudinally-controlled climatic zones. Temperature gradients in mountains may also represent an analogue to those related to latitude since the mean annual temperature (MAT) decreases with increasing in both altitude and latitude. This makes mountain regions well-suited for the study of climate impacts because of the pronounced climatic gradients on a comparatively small scale [18].

The altitude-induced environmental conditions have been reported to influence soil microbial communities in mountains. For example, a decrease in fungal biomass [19] and diversity [20] with increasing altitude were observed in the Austrian Central Alps. A negative correlation between bacterial population and altitude was reported by $\mathrm{Ma}$ et al. [21] in the cold temperate Kalasi Lake and by Giri et al. [22] in a tropical dry deciduous forest. Margesin et al. [19] pointed out several shifts in microbial community composition with altitude in the Austrian Central Alps, such as a significant increase in the relative abundance of fungi and Gram-negative $\left(\mathrm{Gm}^{-}\right)$bacteria. In contrast, Männistö et al. [23] reported that altitude-varied changes in microbial community composition were controlled by $\mathrm{pH}$ rather than temperature fluctuations in Arctic fjelds of Finnish Lapland. Shen et al. [24] also found that soil $\mathrm{pH}$ drives the spatial distribution of bacterial communities along elevation on Changbai Mountain with a bar-coded pyrosequencing technique. Moreover, Djukic et 


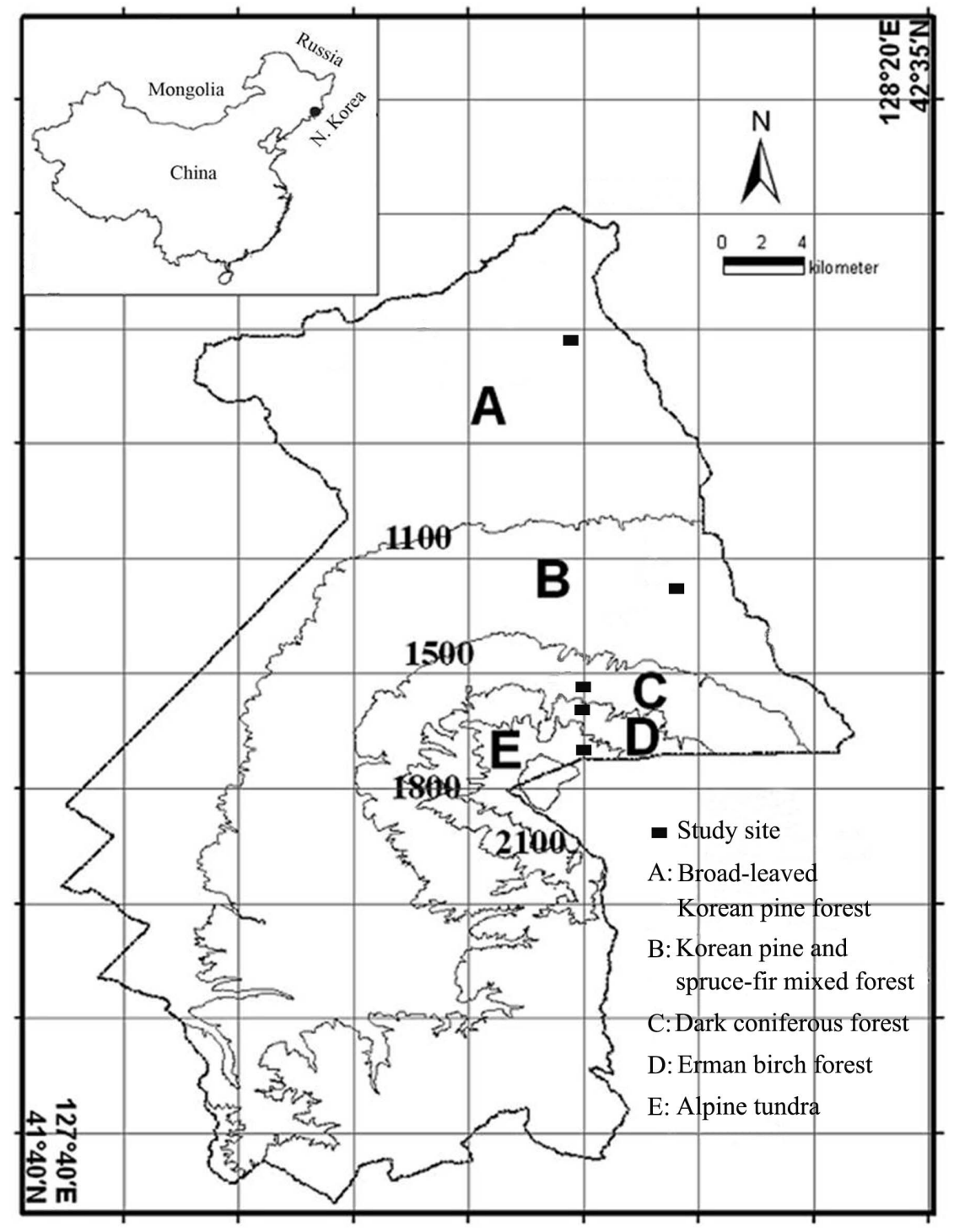

Figure 1. Map of study area and the five vertical vegetation belts along the northern slope of Changbai Mountain, China. The locations of the study sites were marked with rectangles. doi:10.1371/journal.pone.0066184.g001

al. [25] indicated that the microbial community structure was connected with decomposition conditions and changes in vegetation composition along an elevation gradient in the Austrian Limestone Alps. These studies suggest that soil microbial communities can resist simple prediction and are linked to a wide range of factors than the mere altitude. On the other hand, anabolic activity of microbial communities contributed to soil organic matter (SOM) pool by introducing a mass of the successive refractory residues. The accumulation of microbial residues is highly dependent on the quantity and quality of substrate inputs during laboratory incubation [26-28], and several field studies have reported that microbial residues could be preferentially decomposed in soils with poor substrate availability [29], [30]. Different plant species can also specifically influence the contents and patterns of microbial residues in both laboratory and field experiments [29], [31]. Amelung et al. [17] demonstrated a parabolic relationship between the microbial residues and MAT in native grassland soils along a climosequence in North America. Because these factors act in concert along altitude, disentangling their interactions is important for understanding and predicting how soil microbial communities and residues respond to future climate change in mountain soils.

Various methods are available to characterize soil microorganisms. Phospholipid fatty acid (PLFA) analysis is widely accepted as a sensitive tool to indicate viable microbial biomass and fingerprint microbial community composition [32]. Amino sugar analysis is also routinely used to indicate the storage of microbial residues [33]. Furthermore, different origins of individual amino sugars could provide important information on the relative contribution of fungi and bacteria to SOM turnover and accumulation [34-36]. The chitin of fungal cell walls is the major source of glucosamine $(\mathrm{GluN})$ in soil, although bacterial cell walls and the exoskeletons of soil invertebrates also make some contribution [37]. Muramic acid (MurA) originates uniquely from bacteria [33], [37]. Despite galactosamine (GalN) accounts for $30-50 \%$ of the amino sugar pool, little is known about its origin [28], [36]. Combining viable microbial biomass indicator (PLFAs) and microbial cell wall residues (amino sugars) might provide important information 
about microbial significance in SOM cycling and storage [38]. However, few studies have considered both methods simultaneously.

The objectives of this study were: (1) to examine soil microbial communities by PLFAs and microbial residues by amino sugars along an altitude gradient of Changbai Mountain; (2) to determine if and how differences in soil microbial communities and residues are correlated with environmental factors; and (3) to explore the control and feedback between PLFAs and amino sugars.

\section{Materials and Methods}

\section{Study area and soil sampling}

This study was conducted on the northern slope of Changbai Mountain in Jilin Province, northeastern China (Figure 1). The permission is issued by Changbai Mountain Administrative Committee. According to the Köppen Climate Classification, the climate of this region is humid continental. From the lowest part of the mountain at $740 \mathrm{~m}$ to the summit at $2691 \mathrm{~m}$, the MAT decreases from 2.8 to $-7.3^{\circ} \mathrm{C}$, the mean annual precipitation (MAP) increases from 750 to $1340 \mathrm{~mm}$ [39]. Climatic and topographic variations along the altitude gradient result in five vertical vegetation belts on the northern slope (Figure 1). Therefore, five study sites (one in each vegetation belt) were selected to represent a climosequence from the montane ecosystems to the subalpine and alpine zones (Figure 1, Table 1). The influence of human activities was minimized by selecting sites that have not been disrupted.

Four replicate soil monoliths $(25 \times 25 \mathrm{~cm})$ were collected from each of the five sites on July 20, 2009. Samples were taken from the A horizon after the litter and humus layer was removed carefully. The horizon thickness varied from 5 to $11 \mathrm{~cm}$. Fieldmoist samples were placed in a plastic bag and kept cool until processed in the laboratory. After removal of visible fresh roots and plant material, the soils were homogenized and passed through a 2-mm sieve. One sub-sample was air-dried for soil chemical analyses. Another sub-sample was freeze-dried and used for PLFA extraction.

\section{Soil chemical analyses}

Soil total $\mathrm{C}$ and $\mathrm{N}$ were determined by dry combustion on ground samples (100-mesh) using a $\mathrm{C} / \mathrm{N}$ analyzer (LECO Corporation, MI, USA). Because these soils are free of carbonates, the total $\mathrm{C}$ content is equivalent to soil organic $\mathrm{C}$ (SOC) content. Soil $\mathrm{pH}$ was measured in a 1:2.5 soil/water suspension. Available phosphorus $(\mathrm{P})$ and potassium $(\mathrm{K})$ were determined, respectively, by Bray-1 method and ammonium acetate extraction method [40]. $\mathrm{NH}_{4}$ and $\mathrm{NO}_{3}$ were extracted with $2 \mathrm{M} \mathrm{KCl}$ and analyzed on a TRAACS 2000 autoanalyzer by using the Berthelot reaction method and cadmium reduction method, respectively.

Amino sugar analysis was conducted according to Zhang and Amelung [41]. Briefly, samples were hydrolyzed with $6 \mathrm{M} \mathrm{HCl}$ at $105^{\circ} \mathrm{C}$ for $8 \mathrm{~h}$, and then the solution was filtered and purified by neutralization. After drying of the supernatant, amino sugars were washed out from the residues using methanol, transformed into aldononitrile derivatives, and then extracted from the aqueous solution with dichloromethane. The amino sugar derivatives were separated on an Agilent 6890A gas chromatography (GC, Agilent Technologies, USA) equipped with an HP-5 capillary column $(30 \mathrm{~m} \times 0.32 \mathrm{~mm} \times 0.25 \mu \mathrm{m})$ and a flame ionization detector (FID). Amino sugars were quantified based on the internal standard myoinositol which was added prior to purification. Methyl-glucamine was used as a recovery standard before derivatization to monitor recovery efficiency. We calculated the total amino sugar content as the sum of the four amino sugars determined. We used GluN as the biomarker for fungal cell-wall residues and MurA for bacterial cell-wall residues. Mannosamine (ManN) is not considered alone due to its ambiguous origin and trace amounts.

\section{Phospholipid fatty acid analysis}

PLFA extraction was conducted for each sample following the procedure of Bligh and Dyer [42] after modifications by Bossio et al. [13]. Briefly, lipids were extracted in a single-phase chloroformmethanol-citrate buffer (1:2:0.8) system. Phospholipids were separated from neutral lipids and glycolipids on silica solid phase extraction columns (Supelco, Inc., Bellefonte, USA). After methylation of the polar lipids, PLFA methyl esters were analyzed by an Agilent 6890A GC equipped with an HP-5 capillary column $(30 \mathrm{~m} \times 0.32 \mathrm{~mm} \times 0.25 \mu \mathrm{m})$ and a FID. Nonadecanoic acid methyl ester (19:0, Sigma-Aldrich) was added as an internal standard when the samples were dissolved in $150 \mu \mathrm{L}$ of hexane before GC analysis. Super purified nitrogen was used as the carrier gas with a flow rate of $0.8 \mathrm{~mL} \mathrm{~min}{ }^{-1}$. The Supelco 37 Component FAME Mix and Bacterial Acid Methyl Esters (Sigma-Aldrich) were used for peak identification and quantification. A total of thirty-four different PLFAs including saturated, monounsaturated, polyunsaturated, cyclopropyl, and methyl fatty acids were identified. Fifteen PLFAs (14:0, i15:0, a15:0, 15:0, i16:0,

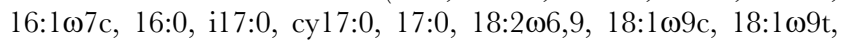
18:0, 20:0) consistently presented in the samples were used for data analysis. The fatty acid signatures 14:0, i15:0, a15:0, 15:0, i16:0, $16: 1 \omega 7 \mathrm{c}$, i17:0, cyl7:0, and 17:0, which are considered to be of bacterial origin [32], were used as biomarkers for bacterial

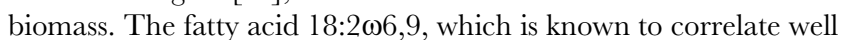
with ergosterol, was used as an indicator for fungal biomass [32]. We used fatty acids i15:0, a15:0, i16:0, and i17:0 to represent

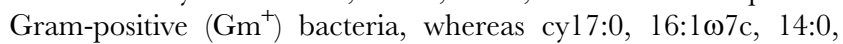
15:0, and 17:0 to represent $\mathrm{Gm}^{-}$bacteria [25]. The sum of all PLFAs was used to represent total microbial lipid biomass.

\section{Statistical analyses}

To explore variation in soil microbial community composition among study sites, the mole percentages $(\mathrm{mol} \%)$ of individual PLFAs were subjected to principal component analysis (PCA) after standardizing to unit variance. To explore the relationships between individual PGs and environmental variables, redundancy analysis (RDA) was carried out with the rda function in the 'vegan' library in R. One-way analysis of variance (ANOVA) procedures, with Tukey's honestly significant difference (HSD) as post hoc, were used to test significant differences in soil properties, sums and ratios of various microbial lipid groups, and concentrations and patterns of amino sugars among study sites. Correlations between variables were calculated with the Pearson correlation coefficients. Statistical analysis was performed using the software package SPSS 13.0 for Windows (SPSS Inc. Chicago, USA). Figures were generated by Sigmaplot 10.0 (Systat Software Inc.) and the R package.

To explore the amino sugar data explained by a linear model of individual PLFAs and soil properties, RDA was carried out again. The ordination of the response variables (amino sugar data) was constrained by a multiple regression on the explanatory variables (individual PLFAs and soil properties). The explanatory PLFAs were selected by three rules: (1) significantly correlated with individual amino sugars; (2) indicative of specific microbial groups; and (3) higher in $\mathrm{mol} \%(>5 \%) . \mathrm{NO}_{3}, \mathrm{~K}$, and $\mathrm{P}$ were excluded from the explanatory variables as they were significantly correlated with SOC. The significance of the RDA results was tested by permutation test (999 permutations). Since $P<0.001$, we presented 

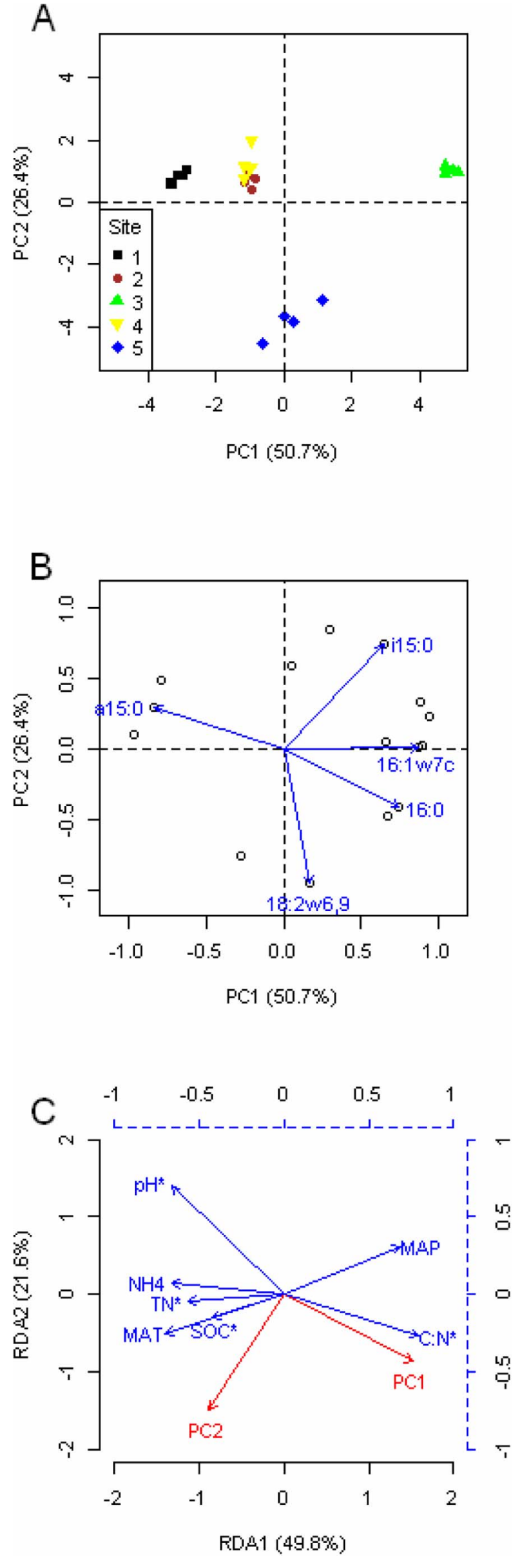

Figure 2. Multivariate statistical analysis of the phospholipids fatty acids (PLFAs) data. A) Principal component analysis (PCA) of PLFAs (mol\%) in different study sites along an altitude gradient on the northern slope of Changbai Mountain, China. PC1 explains $50.7 \%$ of the variance in the PLFA data, PC2 explains $26.4 \%$. Sites $1-5$ represent a climosequence from the montane to the subalpine and alpine vegetation zones. B) Loading plot for individual PLFAs. The PLFAs most responsible for the variations in soil microbial community composition among study sites were presented by vectors. C) Redundancy analysis (RDA) ordination biplot showing relationships between the first two PCs and environmental variables. The environmental variables followed by an asterisk indicate significant influences on the PCs. Environmental variables are scaled by the blue dashed axes. SOC, soil organic carbon; $\mathrm{TN}$, total nitrogen; MAT, mean annual air temperature; MAP, mean annual precipitation.

doi:10.1371/journal.pone.0066184.g002

the ordination biplot which shows sites as points, amino sugars, individual PLFAs, and soil properties as vectors. The angles in the biplot between response and explanatory variables, and between response variables themselves or explanatory variables themselves, reflect their correlations. The proportion of explained variation was calculated by using adjusted R-squared values as described by Peres-Neto et al. [43]. The biplot was generated by the $\mathrm{R}$ package.

\section{Results}

\section{Soil characteristics}

Selected soil characteristics were significantly different among study sites $(P<0.05$, Table 1). Although MAT decreases and MAP increases with increasing elevation, there was no altitudinal changing trend for these soil properties. However, if we excluded site 2 from the study sites, a significant decrease was observed in SOC with increasing altitude $(P<0.05$, Table 1$)$. The $\mathrm{C} / \mathrm{N}$ ratios varied from 14.9 to 21.2 , with the lowest value found at the site that is dominated by broadleaf trees (site 1) and the highest at the site with the highest percentage of conifers (site 3). All study sites were acidic (Table 1). The lowest soil $\mathrm{pH}$ (3.95) was found at the site with the highest $\mathrm{C} / \mathrm{N}$ ratio (site 3) and the highest (5.10) at the site with the lowest $\mathrm{C} / \mathrm{N}$ ratio (site 1 ). Soil available $\mathrm{P}, \mathrm{K}$, and inorganic $\mathrm{N}\left(\mathrm{NH}_{4}+\mathrm{NO}_{3}\right)$ ranged from 8.10-27.2, 163-300, and 53.0-123 $\mathrm{mg} \mathrm{kg}^{-1}$, respectively (Table 1).

\section{Phospholipid fatty acids}

Total microbial lipid biomass was significantly higher in site 1 (302 $\mathrm{nmol} \mathrm{g}^{-1}$ soil) and significantly lower in sites 2, 4, and 5 $\left(125-129 \mathrm{nmol} \mathrm{g}^{-1}\right.$ soil) in comparison with site $3\left(195 \mathrm{nmol} \mathrm{g}^{-1}\right.$ soil, $P<0.05)$. Total microbial lipid biomass was positively correlated with SOG $(r=0.99, P<0.01)$, inorganic N $(r=0.80$, $P<0.01)$, available $\mathrm{P}(r=0.81, P<0.01)$ and $\mathrm{K}(r=0.92, P<0.01)$.

Principal component analysis of the PLFA data suggested substantial differences in soil microbial community composition among study sites (Figure 2A). The first principal component (PC1) explained $50.7 \%$ and the second (PC2) $26.4 \%$ of the total variance in the PLFAs. PC1 was negatively correlated with soil $\mathrm{pH}$ $(r=-0.92, P<0.001)$ and positively with $\mathrm{C} / \mathrm{N}$ ratio $(r=0.82$, $P<0.001$ ) (Figure 2C). The site with the highest $\mathrm{pH}$ and lowest $\mathrm{C} /$ $\mathrm{N}$ ratio (site 1 ) was found on the left-hand side of Figure 2A, the sites with intermediate $\mathrm{pH}$ values and $\mathrm{C} / \mathrm{N}$ ratios (sites 2,4 , and 5) in the middle portion of Figure 2A, and the site with the lowest $\mathrm{pH}$ and highest $\mathrm{C} / \mathrm{N}$ ratio (site 3 ) on the right-hand side of Figure 2A. Along the PC2 axis, the alpine tundra (site 5) showed negative scores, while the forest sites (sites 1-4) showed positive scores. The PCA plot also showed that data points for sites 2 and 4 were intermixed (Figure 2A). For PG1, lipid signatures i15:0, 16:0, and 16:1 $\omega 7 \mathrm{c}$ had higher positive loading scores while a15:0 had lower 
negative loading scores (Figure 2B). For PC2, the fungal biomarker 18:2 $\omega 6,9$ had large negative loading scores and appeared to become less abundant in sites 1-4 than site 5 (Figure 2B).

The absolute abundance of specific microbial groups showed different patterns along the altitude gradient. Site 1 contained $31.9 \%$ higher $(P<0.05)$ bacterial PLFAs than site 3, while it had similar concentration of fungal PLFA as site 3 (Figure 3). Both bacterial and fungal PLFAs in sites 2 and 4 were similar $(P>0.05)$, but significantly lower than those in sites 1 and $3(P<0.05$, Figure 3). Site 5 had the highest fungal PLFA and lowest bacterial PLFAs, which resulted directly in significantly higher fungi to bacteria $(\mathrm{F} /$ B) ratio than other sites $(P<0.05$, Figure 3$)$. Significantly higher F/ $\mathrm{B}$ ratios were also observed in sites 2 and 3 than sites 1 and 4 $\left(P<0.05\right.$, Figure 3). The ratios of $\mathrm{Gm}^{+} / \mathrm{Gm}^{-}$were significantly lower in sites 3 and 5 than sites 1,2 , and $4(P<0.05$, Figure 3$)$.

\section{Amino sugars}

For the study sites, the concentrations of individual amino sugars varied from 1793 to $7205 \mu \mathrm{g} \mathrm{GluN} \mathrm{g}^{-1}$ soil, from 586 to $2431 \mu \mathrm{g}$ GalN g ${ }^{-1}$ soil, and from 105 to $413 \mu \mathrm{g} \mathrm{MurA} \mathrm{g}^{-1}$ soil (Figure 4). All three amino sugars had significantly greater concentrations at site $1(P<0.05)$. GluN was significantly higher in sites 3 and 4 and significantly lower in site 5 compared with site $2(P<0.05)$, while GalN decreased in the order site $4>$ site $3>$ site $5>$ site 2 (Figure 4). MurA was not significantly different among sites $2-5$ ( $P>0.05$, Figure 4). Both GluN/GalN and GluN/MurA ratios were significantly higher in sites 2 and 3 than sites 1 and 5 $(P<0.05$, Figure 4). Site 4 had similar GluN/GalN ratio as sites 1 and 5 and similar GluN/MurA ratio as sites 2 and $3(P>0.05$, Figure 4). Total amino sugars varied in the same way as GluN did, with values ranging from 2656 to $10357 \mu \mathrm{g} \mathrm{g}^{-1}$ soil, and were positively correlated with SOG $(r=0.97, P<0.01)$, inorganic $\mathrm{N}$ $(r=0.91, P<0.01)$, available $\mathrm{P}(r=0.84, P<0.01)$, and available $\mathrm{K}$ $(r=0.97, P<0.01)$. Total amino sugar amounts in SOC (AS/SOC) were significantly higher in sites 1 and 4 (60.5 and $59.5 \mathrm{mg} \mathrm{g}^{-1}$ respectively) and significantly lower in sites 3 and 5 (40.1 and $44.7 \mathrm{mg} \mathrm{g}^{-1}$ respectively) in comparison with site $2\left(54.0 \mathrm{mg} \mathrm{g}^{-1}\right.$, $P<0.05)$.

\section{Relationships between amino sugars and PLFAs}

RDA showed that the first and second canonical axes explained $28.6 \%$ and $7.3 \%$, respectively, of the total variance in the amino sugar data (Figure 5). Because ecological data are generally quite noisy, we can be confident that the major trends have been modeled in this analysis. Furthermore, the first unconstrained eigenvalue is comparatively small, which means that it does not display any important residual structure of the amino sugar data. The amino sugar data appeared to fall into two groups in the ordination biplot, which can be described as: (1) fungal-derived GluN; and (2) GalN and bacterial-derived MurA. Both groups seemed positively correlated with a15:0, i17:0, SOC, and TN. Permutation test by terms revealed a15:0, i15:0, i16:0, i17:0, $16: 1 \omega 7 \mathrm{c}$ and SOC had significant influence on amino sugar data. In addition, the study sites in the ordination biplot were clearly separated.

\section{Discussion}

In this study, we examined soil microbial communities and residues along an elevation gradient of Changbai Mountain. We found neither soil microbial communities nor residues showed a consistent altitudinal change along the studied elevation gradient. Similar altitudinal trends in microbial communities were found in Austrian Limestone Alps [25] and Bornean tropical forest ecosystems [44]. In contrast, Margesin et al. [19] observed a decrease of microbial (bacterial and fungal) biomass with increasing altitude in the Austrian Central Alps. One possible explanation for the apparent disparity between studies lies in site selection. For example, Djukic et al. [25] selected six study sites in

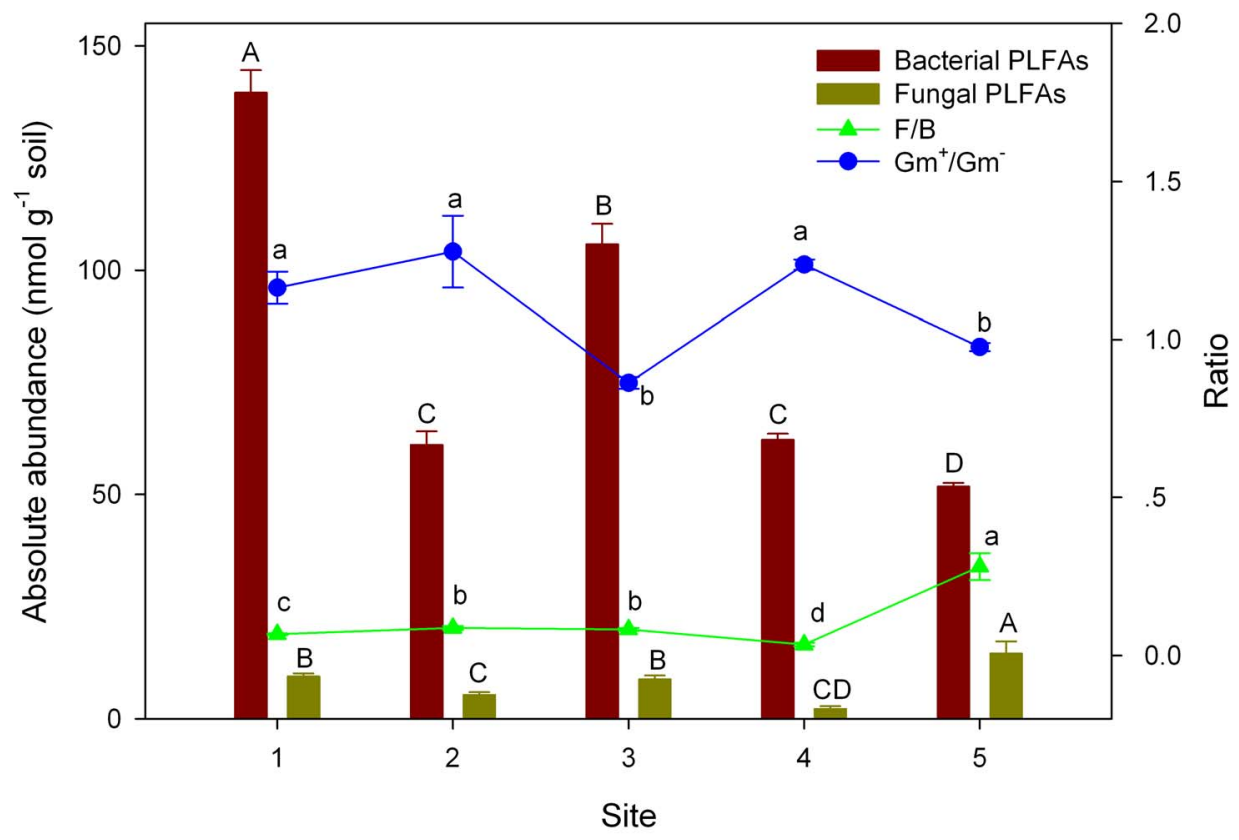

Figure 3. Sums and ratios of phospholipid fatty acids (PLFAs) of various microbial groups in different study sites along an altitude gradient on the northern slope of Changbai Mountain, China. Different letters within each group indicate significant differences among study sites $\left(P<0.05\right.$, Tukey's HSD). Error bars show standard errors $(n=4)$. F/B, the ratio of fungal to bacterial PLFAs; $\mathrm{Gm}^{+} / \mathrm{Gm}^{-}$, the ratio of Grampositive to Gram-negative bacteria.

doi:10.1371/journal.pone.0066184.g003 


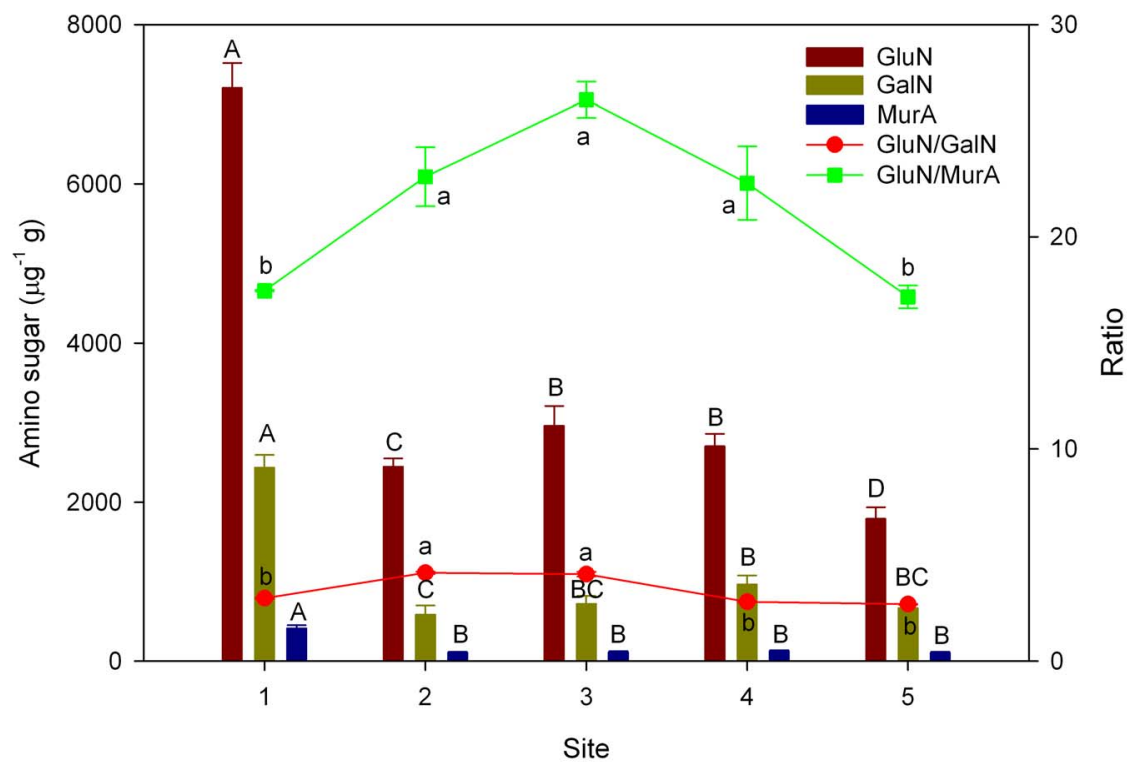

Figure 4. Concentrations and patterns of amino sugars in different study sites along an altitude gradient on the northern slope of Changbai Mountain, China. Different letters within each group indicate significant differences among study sites $(P<0.05$, Tukey's HSD). Error bars show standard errors $(n=4)$. GluN, glucosamine; GalN, galactosamine; MurA, muramic acid. doi:10.1371/journal.pone.0066184.g004

$\begin{array}{cccc}-1 & -0.5 & 0 & 0.5 \\ \text { L } & - & - & -1\end{array}$

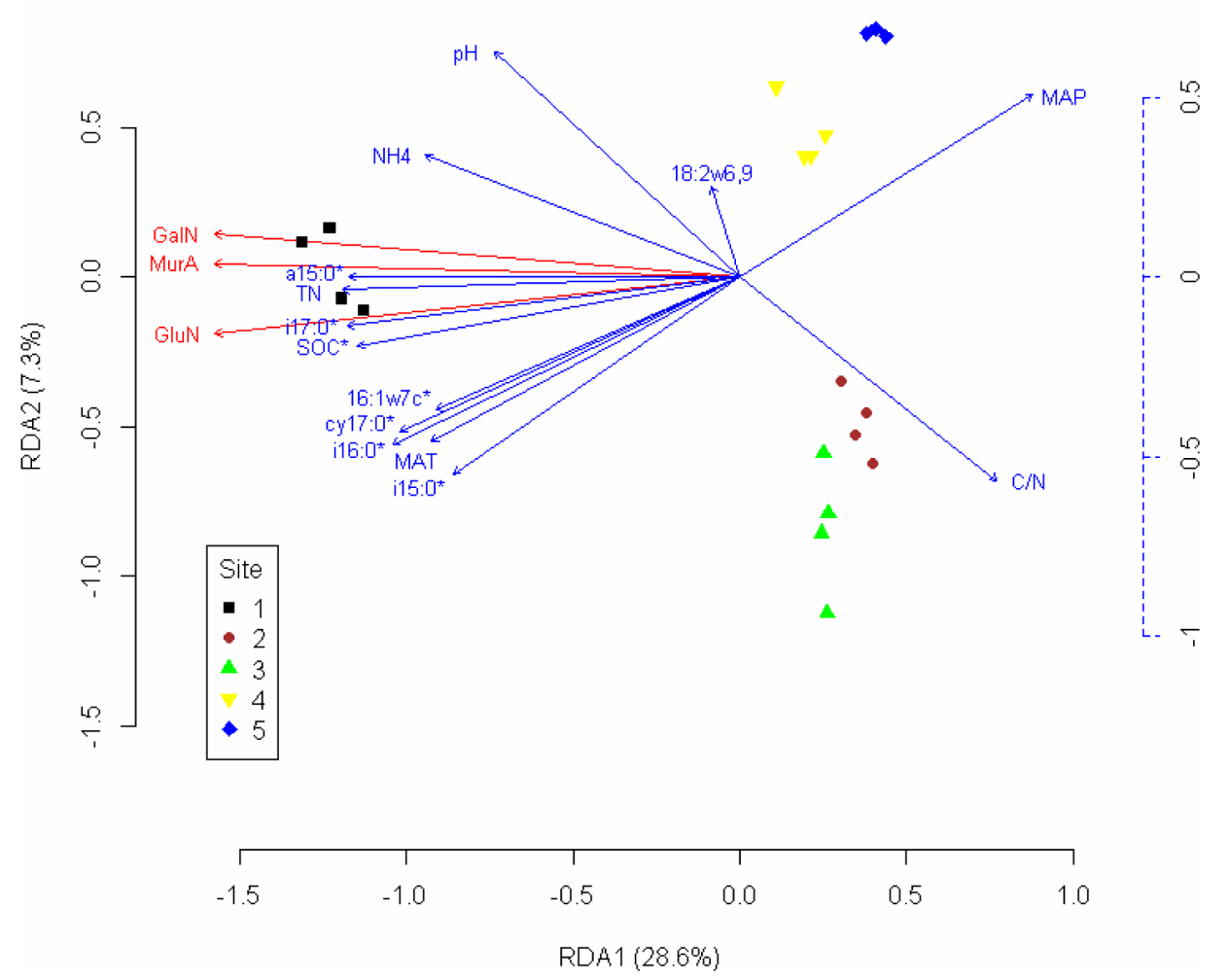

Figure 5. Redundancy analysis (RDA) of the amino sugar data for 20 soil samples using 7 microbial lipids and 7 environmental properties as explanatory variables. The amino sugars and sites are scaled by the black solid axes (bottom and left), and the explanatory variables are scaled by the blue dashed axes (top and right). The explanatory variables followed by an asterisk indicate significant influences on the amino sugar data.The proportion of explained variation was calculated by using adjusted R-squared values as described by Peres-Neto et al. [43]. GluN, glucosamine; GalN, galactosamine; MurA, muramic acid; SOC, soil organic carbon; TN, total nitrogen; MAT, mean annual air temperature; MAP, mean annual precipitation.

doi:10.1371/journal.pone.0066184.g005 
200-m elevation increments from 900 to $1900 \mathrm{~m}$, whereas Margesin et al. [19] compared microbial communities only between alpine (2300-2530 m) and subalpine (1500-1900 m) soils. Because there was no available study regarding microbial residues along altitude, we compared our amino sugar data with the results from latitudinal studies. While Sowden [45] did not find any correlation between amino sugars and climatic elements in Canadian soils from different climate and vegetation zones, Amelung et al. [17] showed a parabolic relationship between amino sugars and MAT along a climosequence in North America. It seems that the effect of altitude on soil microbial communities and residues was indirect and mainly through its control on vegetation inputs and microbial habitat in our study. Alternatively, it could be that the control mechanism of altitude was more complex than simple linear relationship.

This study indicated that soil $\mathrm{pH}$ and $\mathrm{C} / \mathrm{N}$ ratio were the most important drivers for soil microbial community composition and residue pattern along the northern slope of Changbai Mountain. Similar forces were found to shape microbial community composition in boreal forest soils [46] and alpine environments [25]. This is also in agreement with the results observed by ribosomal RNA gene based analysis on the same mountain [24]. The site with the lowest $\mathrm{pH}$ and highest $\mathrm{C} / \mathrm{N}$ ratio (site 3) was structurally distinct from the other sites as a consequence of higher relative abundance of i15:0, 16:1 $107 \mathrm{c}$, and 16:0 and lower relative abundance of a15:0. Significantly higher i15:0/a15:0 ratio (3.75) in this site than other sites $(1.57-1.71)$ indicated niche stress for microbial growth. This is in line with report of increased i15:0 and decreased a 15:0 in low $\mathrm{pH}$ oak forest soils [47]. However, Nilsson et al. [47] also found the PLFA 16:1 $107 \mathrm{c}$ was associated with high $\mathrm{pH}$ in forest soils, which seems to contrast with our results. Disparities might be explained if other methods determining microbial community composition at higher resolution were included, such as ribosomal RNA gene based analysis [24]. The lower $\mathrm{Gm}^{+} / \mathrm{Gm}^{-}$ratio in this site probably contributed to its higher GluN/MurA ratio because cell wall of $\mathrm{Gm}^{-}$bacteria contains thinner murein layers than that of $\mathrm{Gm}^{+}$bacteria, leading to lower MurA concentrations in living $\mathrm{Gm}^{-}$than $\mathrm{Gm}^{+}$bacteria [48], [49].

It is generally held that soils with high $\mathrm{pH}$ and low $\mathrm{C} / \mathrm{N}$ ratio are more favourable to bacteria than fungi, and vice versa [50], [51]. This supports our result of fungal dominance at sites 2 and 3 and bacterial dominance at sites 1 and 4 (Figure 3, Table 1). Our observations are consistent with reports of increased $\mathrm{F} / \mathrm{B}$ ratios in low $\mathrm{pH}$ coniferous forest soils than in high $\mathrm{pH}$ beech forest soils [32]. The influence of soil $\mathrm{pH}$ and $\mathrm{C} / \mathrm{N}$ ratio on the relative abundance of fungi and bacteria in the studied forest sites was well reflected in GluN/GalN ratio (Figure 3, 4). An increasing GluN/ GalN ratio has been used to indicate an increasing fungal contribution to SOM humification in forests [37]. Liang et al. [38] reported that of three forest soils, the one with the highest $\mathrm{F} / \mathrm{B}$ ratio showed the highest fungal contribution to the soil amino sugar pool, which is in line with our study. However, such reflection was not observed in heavy metal polluted soils [52] or agricultural soils under contrast tillage practices [53]. Our results substantiate the "memory effect" of microbial residues which integrate microbial community structure over time [28], [54].

A negative correlation was found between $\mathrm{C} / \mathrm{N}$ ratios and the ratios of total amino sugars to total PLFAs $(r=-0.86, P<0.01)$. This corresponds well with the study of Liang et al. [38] in which a decrease in the ratio of amino sugars to PLFAs was associated with an increase in $\mathrm{C} / \mathrm{N}$ ratio. This result could be explained by selective preservation which is a common humification pathway in forest soils [55]. For example, site 3 contained a relatively higher

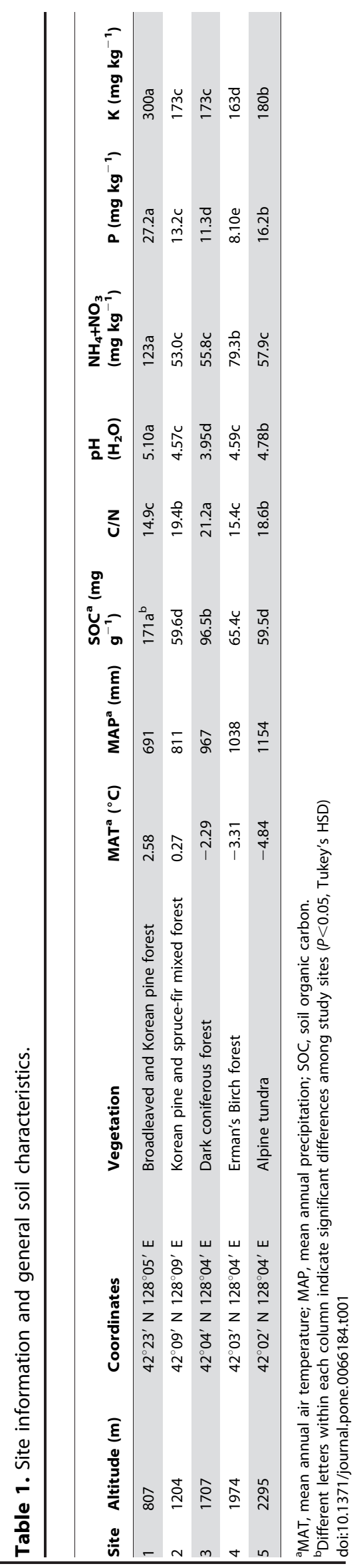


living biomass (Figure 3). However, due to the poor quality of substrate ( $\mathrm{C} / \mathrm{N}$ ratio, 21.2), amino sugars might be decomposed and served as a preferred substrate for microorganisms to meet their growth needs. This is also the case for sites 2 and 5 with $\mathrm{C} / \mathrm{N}$ ratios of 19.4 and 18.6, respectively, resulting in significantly lower microbial contribution to SOM pools (AS/SOC) in those sites than sites 1 and 4 .

The significant correlation between nutrient availability and PLFAs as well as amino sugars indicated a strong substrate control over microbial communities and their residues. Substrate availability was also found to influence soil microbial communities in Bornean tropical forests [44] and soil microbial residues in a Michigan old-growth forest [29]. Soil microorganisms are usually considered to be $\mathrm{C}$ limited [56], even in coniferous forest soils with high soil $\mathrm{C} / \mathrm{N}$ ratios [57] such as site 3 of our study. In this study, individual amino sugars contributed to the total in the order GluN $>$ GalN $>$ MurA, which is consistent with results from other forest soils [29], [58], native grassland soils [17], and agricultural soils [30], [59].

Despite a few studies found significant tree species-specific effects on soil microbial communities [5], [6] and residues [29], we put less focus on vegetation since Ushio et al. [60] pointed out tree species influence soil microbial community mainly through their effects on soil $\mathrm{pH}$, total $\mathrm{G}$ and $\mathrm{N}$. Nevertheless, the fungal dominance of the coniferous forests (sites 2 and 3) in our study could be partially explained by vegetation types. Fungi are thought to be more efficient in the decomposition of recalcitrant phenolic compounds [6] which have been identified with high quantities in coniferous forest [61]. In addition, ectomycorrhizal fungi could partially contribute to the fungal biomass since they exist in a symbiotic relationship with various species of coniferous trees [62].

The findings of this research also provide some insight into the relationships between soil microbial communities and their residues, as indicated by the relationships between the PLFA and amino sugar signatures in the ordination biplot. The positive correlations of amino sugars with bacterial-derived PLFAs suggest that variations in bacterial communities could lead to changes in amino sugars. It seems that bacteria, especially $\mathrm{Gm}^{+}$bacteria, played a more important role in the turnover and accumulation of

\section{References}

1. Lucas RW, Casper BB, Jackson JK, Balser TC (2007) Soil microbial communities and extracellular enzyme activity in the New Jersey Pinelands. Soil Biol Biochem 39: 2508-2519.

2. Liang C, Cheng G, Wixon DL, Balser TC (2011) An Absorbing Markov Chain approach to understanding the microbial role in soil carbon stabilization. Biogeochemistry 106: 303-309.

3. Stroud JL, Paton GI, Semple KT (2007) Microbe-aliphatic hydrocarbon interactions in soil: Implications for biodegradation and bioremediation. J Appl Microbiol 102: 1239-1253.

4. Singh BK, Bardgett RD, Smith P, Reay DS (2010) Microorganisms and climate change: Terrestrial feedbacks and mitigation options. Nat Rev Microbiol 8: 779 790 .

5. Bach LH, Grytnes JA, Halvorsen R, Ohlson M (2010) Tree influence on soil microbial community structure. Soil Biol Biochem 42: 1934-1943.

6. Hackl E, Pfeffer M, Donat C, Bachmann G, Zechmeister-Boltenstern S (2005) Composition of the microbial communities in the mineral soil under different types of natural forest. Soil Biol Biochem 37: 661-671.

7. Weand MP, Arthur MA, Lovett GM, McCulley RL, Weathers KC (2010) Effects of tree species and $\mathrm{N}$ additions on forest floor microbial communities and extracellular enzyme activities. Soil Biol Biochem 42: 2161-2173.

8. Liang C, Jesus EC, Duncan DS, Jackson RD, Tiedje JM, et al. (2012) Soil microbial communities under model biofuel cropping systems in southern Wisconsin, USA: Impact of crop species and soil properties. Appl Soil Ecol 54: 24-31.

9. Pettersson M, Bååth E (2003) Temperature-dependent changes in the soil bacterial community in limed and unlimed soil. FEMS Microb Ecol 45: 13-21.

10. Brockett BFT, Prescott CE, Grayston SJ (2012) Soil moisture is the major factor influencing microbial community structure and enzyme activities across seven biogeoclimatic zones in western Canada. Soil Biol Biochem 44: 9-20. amino sugars. The significant correlation between $\mathrm{Gm}^{+} / \mathrm{Gm}^{-}$and AS/SOC $(r=0.83, P<0.01)$ supports this point. Fungal PLFA $18: 2 \omega 6,9$, on the other hand, did not show a significant influence on amino sugar data despite the fungal-derived GluN accounted $67.5-76.5 \%$ of the total amino sugar pool. The significant influence of SOC on amino sugar data is consistent with the substrate control discussed above. Nevertheless, it remains a significant challenge to determine how the changes in microbial communities that occur under different environmental conditions could be manifested in changes in microbial residues.

\section{Conclusions}

In this study, we examined soil microbial communities and residues along an elevation gradient of Changbai Mountain by analyzing PLFA and amino sugar signatures. We found both soil microbial communities and residues differ between sites, thus reflecting variations between sites in several biotic and abiotic factors. However, the differences were not related to altitude, suggesting either the control of altitude is indirect or the mechanism is complex than simple linear relationship with soil microbial communities and residues. We found soil $\mathrm{pH}$ and $\mathrm{C} / \mathrm{N}$ ratio were the most important drivers for microbial community structure and amino sugar pattern, while substrate availability was of great importance in determining the concentrations of microbial communities and residues. Redundancy analysis indicated bacteria were more important in controlling the feedback with amino sugar pools than fungi.

\section{Acknowledgments}

We would like to thank Xiaobo Li, Qiuxiang Tian, and Yang Wang for their help with the soil sampling.

\section{Author Contributions}

Conceived and designed the experiments: BZ XDZ. Performed the experiments: BZ. Analyzed the data: BZ CL. Contributed reagents/ materials/analysis tools: HBH XDZ. Wrote the paper: BZ.

11. Bååth E, Anderson TH (2003) Comparison of soil fungal/bacterial ratios in a $\mathrm{pH}$ gradient using physiological and PLFA-based techniques. Soil Biol Biochem 35: 955-963.

12. Rousk J, Brookes PC, Bååth E (2010) The microbial PLFA composition as affected by $\mathrm{pH}$ in an arable soil. Soil Biol Biochem 42: 516-520.

13. Bossio DA, Scow KM, Gunapala N, Graham KJ (1998) Determinants of soil microbial communities: Effects of agricultural management, season, and soil type on phospholipid fatty acid profiles. Microb Ecol 36: 1-12.

14. Fierer N, Schimel JP, Holden PA (2003) Variations in microbial community composition through two soil depth profiles. Soil Biol Biochem 35: 167-176.

15. Wu Y, Ma B, Zhou L, Wang H, Xu J, et al. (2009) Changes in the soil microbial community structure with latitude in eastern China, based on phospholipid fatty acid analysis. Appl Soil Ecol 43: 234-240.

16. Yergeau E, Bokhorst S, Huiskes AHL, Boschker HTS, Aerts R, et al. (2007) Size and structure of bacterial, fungal and nematode communities along an Antarctic environmental gradient. FEMS Microb Ecol 59: 436-451.

17. Amelung W, Zhang X, Flach KW, Zech W (1999) Amino sugars in native grassland soils along a climosequence in North America. Soil Sci Soc Am J 63: 86-92.

18. Diaz HF, Grosjean M, Graumlich L (2003) Climate variability and change in high elevation regions: Past, present and future. Climatic Change 59: 1-4.

19. Margesin R, Jud M, Tscherko D, Schinner F (2009) Microbial communities and activities in alpine and subalpine soils. FEMS Microb Ecol 67: 208-218.

20. Schinner F, Gstraunthaler G (1981) Adaptation of microbial activities to the environmental conditions in alpine soils. Oecologia 50: 113-116.

21. Ma X, Chen T, Zhang G, Wang R (2004) Microbial community structure along an altitude gradient in three different localities. Folia Microbiologica 49: 105111. 
22. Giri DD, Shukla PN, Kashyap S, Singh P, Kashyap AK, et al. (2007) Variation in methanotrophic bacterial population along an altitude gradient at two slopes in tropical dry deciduous forest. Soil Biol Biochem 39: 2424-2426.

23. Männistö MK, Tiirola M, Häggblom MM (2007) Bacterial communities in Arctic fjelds of Finnish Lapland are stable but highly pH-dependent. FEMS Microb Ecol 59: 452-465.

24. Shen C, Xiong J, Zhang H, Feng Y, Lin X, et al. (2013) Soil pH drives the spatial distribution of bacterial communities along elevation on Changbai Mountain. Soil Biol Biochem 57: 204-211.

25. Djukic I, Zehetner F, Mentler A, Gerzabek MH (2010) Microbial community composition and activity in different Alpine vegetation zones. Soil Biol Biochem 42: 155-161.

26. Engelking B, Flessa H, Joergensen RG (2007) Shifts in amino sugar and ergosterol contents after addition of sucrose and cellulose to soil. Soil Biol Biochem 39: 2111-2118.

27. Liang C, Zhang X, Balser TC (2007b) Net microbial amino sugar accumulation process in soil as influenced by different plant material inputs. Biol Fertil Soils 44: $1-7$.

28. He H, Zhang W, Zhang X, Xie H, Zhuang J (2011) Temporal responses of soil microorganisms to substrate addition as indicated by amino sugar differentiation. Soil Biol Biochem 43: 1155-1161.

29. Liang G, Fujinuma R, Wei L, Balser TC (2007a) Tree species-specific effects on soil microbial residues in an upper Michigan old-growth forest system. Forestry 80: $65-72$.

30. Ding XL, Zhang B, Zhang XD, Yang XM, Zhang XP (2011) Effects of tillage and crop rotation on soil microbial residues in a rainfed agroecosystem of northeast China. Soil Till Res 114: 43-49.

31. Liang C, Zhang X, Rubert IV KF, Balser TC (2007c) Effect of plant materials on microbial transformation of amino sugars in three soil microcosms. Biol Fertil Soils 43: 631-639.

32. Frostegård A, Bååth E (1996) The use of phospholipid fatty acid analysis to estimate bacterial and fungal biomass in soil. Biol Fertil Soils 22: 59-65.

33. Amelung W (2001) Methods using amino sugars as markers for microbial residues in soil. In: Lal R, Kimble JM, Follett RF, Stewart BA, editors. Assessment Methods for Soil Carbon. Boca Raton: CRC/Lewis Publishers. pp. $223-270$.

34. Zhang X, Amelung W, Yuan Y, Zech W (1998) Amino sugar signatures of particle size fractions in soils of the native prairie as affected by climate. Soil Sci 63: 220-229.

35. Zhang X, Wang J, Xie HT, Wang JK, Zech W (2003) Comparison of organic compounds in the particle-size fractions of earthworm casts and surrounding soil in humid Laos. Appl Soil Ecol 23: 147-153

36. Joergensen RG, Mäder P, Fließbach A (2010) Long-term effects of organic farming on fungal and bacterial residues in relation to microbial energy metabolism. Biol Fertil Soils 46: 303-307.

37. Parsons JW (1981) Chemistry and distribution of amino sugars in soils and soil organisms. In: Paul EA, Ladd JN, editors. Soil Biochemistry. New York: Marcel Dekker. pp. 197-227.

38. Liang C, Fujinuma R, Balser TC (2008) Comparing PLFA and amino sugars for microbial analysis in an Upper Michigan old growth forest. Soil Biol Biochem 40: 2063-2065.

39. He HS, Hao Z, Mladenoff DJ, Shao G, Hu Y, et al. (2005) Simulating forest ecosystem response to climate warming incorporating spatial effects in northeastern China. J Biogeogr 32: 2043-2056.

40. Lu RK (2000) Methods of Soil and Agro-chemistry. Beijing: Chinese Agricultural Science and Technology Press.
41. Zhang X, Amelung W (1996) Gas chromatographic determination of muramic acid, glucosamine, mannosamine, and galactosamine in soils. Soil Biol Biochem 28: 1201-1206.

42. Bligh EG, Dyer WJ (1959) A rapid method of total lipid extraction and purification. Can J Biochem Phys 37: 911-917.

43. Peres-Neto PR, Legendre P, Dray S, Borcard D (2006) Variation partitioning of species data matrices: estimation and comparison of fractions. Ecology 87: 2614 2625 .

44. Wagai R, Kitayama K, Satomura T, Fujinuma R, Balser T (2011) Interactive influences of climate and parent material on soil microbial community structure in Bornean tropical forest ecosystems. Ecol Res 26: 627-636.

45. Sowden FJ (1977) Distribution of nitrogen in representative Canadian soils. Can J Soil Sci 57: 445-456.

46. Högberg MN, Högberg P, Myrold DD (2007) Is microbial community composition in boreal forest soils determined by $\mathrm{pH}$, C-to-N ratio, the trees, or all three? Oecologia 150: 590-601.

47. Nilsson LO, Bååth E, Falkengren-Grerup U, Wallander H (2007) Growth of ectomycorrhizal mycelia and composition of soil microbial communities in oak forest soils along a nitrogen deposition gradient. Oecologia 153: 375-384.

48. Millar WN, Casida LE (1970) Evidence for muramic acid in soil. Can J Microb 16: 299-304.

49. Eudy LW, Walla MD, Morgan SL, Fox A (1985) Gas chromatographic-mass spectrometric determination of muramic acid content and pyrolysis profiles for a group of gram-positive and gram-negative bacteria. The Analyst 110: 381-385.

50. Alexander M (1977) Introduction to Soil Microbiology, second edition. New York: Wiley.

51. Sterner RW, Elsner JJ (2002) Ecological Stoichiometry: The Biology of Elements from Molecules to the Biosphere. Princeton: Princeton University Press.

52. Kandeler E, Tscherko D, Bruce KD, Stemmer M, Hobbs PJ, et al. (2000) Structure and function of the soil microbial community in microhabitats of a heavy metal polluted soil. Biol Fertil Soils 32: 390-400.

53. van Groenigen KJ, Bloem J, Bååth E, Boeckx P, Rousk J, et al. (2010) Abundance, production and stabilization of microbial biomass under conventional and reduced tillage. Soil Biol Biochem 42: 48-55.

54. Glaser B, Turrión MB, Alef K (2004) Amino sugars and muramic acid Biomarkers for soil microbial community structure analysis. Soil Biol Biochem 36: 399-407.

55. Kögel-Knaber I (1993) Biodegradation and humification processes in forest soils. In: Bollag JM, Stotsky G, editors. Soil Biochemistry. New York: Marcel Dekker Inc. pp. 101-135.

56. Wardle DA (1992) A comparative assessment of factors which influence microbial biomass carbon and nitrogen levels in soil. Biol Rev 67: 321-358.

57. Allen AS, Schlesinger WH (2004) Nutrient limitations to soil microbial biomass and activity in loblolly pine forests. Soil Biol Biochem 10: 215-221.

58. Moritz LK, Liang C, Wagai R, Kitayama K, Balser TC (2009) Vertical distribution and pools of microbial residues in tropical forest soils formed from distinct parent materials. Biogeochemistry 92: 83-94.

59. Guggenberger G, Frey SD, Six J, Paustian K, Elliott ET (1999) Bacterial and fungal cell-wall residues in conventional and no-tillage agroecosystems. Soil Sci Soc Am J 63: 1188-1198.

60. Ushio M, Wagai R, Balser TC, Kitayama K (2008) Variations in the soil microbial community composition of a tropical montane forest ecosystem: Does tree species matter? Soil Biol Biochem 40: 2699-2702.

61. Gallet C, Pellissier F (1997) Phenolic compounds in natural solutions of a coniferous forest. J Chem Ecol 23: 2401-2412.

62. Smith SE, Read DJ (1997) Mycorhizal symbiosis. San Diego: Academic Press. 